\title{
Covid-19: Drug firms warn stockpiles have been eroded amid fears of no deal Brexit
}

\author{
Gareth lacobucci
}

The BMJ

Drug industry leaders have warned the UK government that stockpiles of some drugs have been eroded by covid-19, leaving supplies even more vulnerable if a no deal Brexit occurs.

In a briefing paper prepared by various industry bodies, obtained by BBC News, ${ }^{1}$ manufacturers reported a surge in demand for medicines during the pandemic, which had left stocks depleted, particularly for drugs used in critical and respiratory care

They warned that it would be difficult for manufacturers to build stocks for the end of this year in preparation for a possible no deal Brexit, as they did for the end of last year.

Industry is urging the government to move fast to stockpile critical drugs in advance of a possible second wave of covid-19, and to strive to avoid a no deal Brexit given the risk of further disruption to drug supply chains.

The government said it "continues to prepare for all scenarios and robust contingency plans are in place."

A government spokesperson said, "We want a relationship with the European Union which is based on friendly cooperation between sovereign equals and centred on free trade."

Warwick Smith, director general of the British Generic Manufacturers Association, one of the organisations that contributed to the briefing, said the UK needed to act fast given the risk of shortages.

In a statement sent to The $B M J$, he said, "Working with the government and the NHS, industry met the huge surge in demand for intensive care drugs during the height of the pandemic. All European governments are now considering how to prepare for a possible second wave given highly depleted stocks, for example by stockpiling critical drugs in advance.
We would support government initiatives of this type. But we must act quickly in the UK to ensure that we are not left behind." Smith added, "A non-negotiated exit from the EU would potentially disrupt supplies of drugs further. Manufacturers concentrated production on intensive care drugs during the pandemic, often switching manufacturing from other products. They will not, therefore, be able to build stocks for the end of this year as they did for the end of last and will need to work with the government on a range of measures to ensure supply." The Association of the British Pharmaceutical Industry (ABPI), which also contributed to the briefing, said drug companies had been working hard during the pandemic to keep supplies flowing and would continue to do so, but said the situation highlighted why it was concerned about a no deal Brexit.

ABPI chief executive Richard Torbet said, "With this pressure likely to continue over the coming months, the pandemic has reinforced why it is essential that the UK and EU reach a deal on their future relationship.

"Not everything is in the gift of industry. Stockpiling is one element—having alternative supply routes and making sure that goods can continue to flow uninterrupted across borders is also critical."

1 Islam F. UK post-Brexit drug stockpiles at risk amid virus. 8 June 2020. www.bbc.co.uk news/business-52959639.

This article is made freely available for use in accordance with BMJ's website terms and conditions for the duration of the covid-19 pandemic or until otherwise determined by BMJ. You may use, download and print the article for any lawful, non-commercial purpose (including text and data mining) provided that all copyright notices and trade marks are retained.

https://bmj.com/coronavirus/usage 